Interdisciplinary Studies of Complex Systems

No. 19 (2021) 94-108

(C) N. Nychkalo, L. Lukianova, L. Khomych

https://doi.org/10.31392/iscs.2021.19.094

378.091.3:373.5.011.3-051

\title{
Cross CURRICULUM INTERACTION IN TEACHER TRAINING AS PEDAGOGICAL REALITY
}

\author{
Nellia Nychkalo ${ }^{1}$, Larysa Lukianova ${ }^{23}$, Lidiia Khomych ${ }^{2,4}$
}

\section{ІНТЕРДИСЦИПЛІНАРНА ВАЄМОДІЯ У ПРОФЕСІЙНІЙ ПІДГОТОВЦІ ВЧИТЕЛЯ ЯК ПЕДАГОГІЧНА РЕАЛЬНІСТЬ}

\author{
Нелля Ничкало, Лариса Лук'янова, Лідія Хомич
}

\begin{abstract}
Rapid process of obsolescence of knowledge, necessity of its constant modernization, differentiation and practical orientation require from teacher professional training a set of conditions, implementation of which needs harmonious combination (integration, complementarity, connection) of different subjects for integrity, thoroughness and effectiveness of such training.

The results of anonymous online survey are presented, which have demonstrated that the majority of teachers in higher educational establishments are aware of crosscurriculum approach, associated with cooperation, complement, help, interaction, as well as the importance of its practical implementation in future teacher training even in the absence of motivation.

The results of the survey allowed the authors to rationalize principles of crosscurriculum approach to the design of the content of future teachers' psychological and pedagogical training, in which principle of integrity is a leading one, with such priority principals as systematic, structural, integrative, hierarchical ones.
\end{abstract}

Keywords: inter-subject principal, cross-curriculum approach, interaction, professional training, teacher

Анотація. Швидке застарівання знань, необхідність їх постійного оновлення, поглиблення диференціації і практичної спрямованості висувають до професійної підготовки вчителя сукупність вимог, задоволення яких потребує органічного поєднання (інтеграції, взаємодоповнення, зв'язку) різних дисциплін задля цілісності, грунтовності й загалом ефективності такої підготовки.

Висвітлено результати анонімного он-лайн опитування, які показали усвідомленість більшістю викладачів закладів вищої освіти ролі міждисцплінарного підходу, що асоціюється у них із сумісною дією, доповненням, допомогою, взаємодією; а також важливість його впровадження у професійну підготовку майбутнього педагога і використання на практиці навіть за умови відсутності мотивації.

\footnotetext{
${ }^{1}$ National Academy of Educational Sciences of Ukraine, Kyiv, Ukraine. napn24@gmail. com, https://orcid.org/0000-0002-5989-5684

${ }^{2}$ Ivan Ziaziun Institute of Pedagogical and Adult Education, National Academy of Educational Sciences of Ukraine, Kyiv, Ukraine.

3 larysa.lukianova@gmail.com, https://orcid.org/0000-0002-0982-6162

4 ukrlida@ukr.net, https://orcid.org/0000-0003-1130-4395
} 
За результатами опитування обгрунтовано принципи міждисциплінарного підходу до побудови змісту професійної психолого-педагогічної підготовки майбутніх педагогів, провідним з яких є принцип цілісності, першорядні позиції також посідають принципи системності, структурності, інтегративності та ієрархічності.

Ключові слова: інтердисциплінарність, міждисциплінарний підхід, взаємодія, професійна підготовка, педагог

\section{Актуальність проблеми}

Інформаційно-технологічне глобалізоване суспільство початку XXI ст. висунуло низку освітньо-наукових проблем, вирішення яких вимагає всебічної онтологізації, методологічної й гносеологічної трансформації соціокультурного знання. Водночас не можемо залишити поза увагою факт, що провідною тенденцією сучасного світу $є-$ поновлення знань, яке радше визначає вектор цілісності знань, аніж їх конкретний зміст, оскільки експоненціальний темп розвитку сучасного динамічного світу візуалізує втрату прикладної цінності спеціалізованих знань через кожні 10-15 років. Це, на думку сучасних вчених, вимагає створення інтегративної парадигми освіти, сформованої на основі міждисциплінарного підходу. Особливості інтегративної парадигми освіти полягають у тому, що вона інтегрує обгрунтовані цілі розвитку людини, а також узагальнює теоретичні та практичні аспекти інших освітніх парадигм [1, с. 413].

У цьому контексті посилюється роль синергетики у вивченні проблеми міждисциплінарного діалогу, зокрема у виявленні особливості сучасних соціальних, когнітивних і комунікативних ситуацій, зіставленні різних наукових точок зору. За таких умов універсалізується методологічна парадигма, формується єдиний міждисциплінарний підхід до досліджуваних предметів та об'єктів. Однак дійсна міждисциплінарність є складним процесом пізнання й осмислення іншої багатовимірної наукової реальності, визначення способу їі використання для вирішення актуальних завдань, зокрема професійної підготовки майбутніх педагогів. Отже оскільки наше дослідження не стосується конкретної майбутньої професійної спеціалізації увагу акцентуємо на інтердисциплінарній співдії, яка грунтується на міждисциплінарному підході і може відбуватися без порушення меж дисципліни, що має місце через методичні особливості її вивчення і викладання, використання теоретичних конструктів, моделей, інтерпретаційних стратегій тощо.

\section{Міждисциплінарний підхід у педагогічній науці}

Підгрунтя міждисциплінарного підходу становить проблема інтеграції - одна з найдавніших в історї розвитку науки. Про єдність наукових знань писали давньогрецькі мислителі (Платон, Аристотель та ін.), науковці нашого століття (Ейнштейн, Вінер та ін.), вітчизняні вчені (І. Павлов, М. Вавілов, В. Амбарпумян, А. Берг, М. Костомаров та ін.).

Серед шляхів інтеграції, які знайшли відображення у філософських джерелах і привертають особливу увагу педагогічної науки найбільш ви- 
разними є синтез знань через взаємодію наук за об'єктом і методом дослідження; синтез знань з подальшою диференціацією.

Ідея реалізації зв'язків між навчальними дисциплінами не нова. На важливості взаємозв'язаного навчання для забезпечення міцності знань учнів наголошував Я.А. Коменський, він уважав, що знання студентів будуть міцними, якщо все, що в природі знаходиться у постійному взаємозв'язку, у такому ж зв'язку викладати студентам. Цю ідею підтримали Дж. Локк, І. Песталоцці, А. Дістервег. Серед українських вчених проблемою міжпредметних зв'язків займалися К. Ушинський, П. Каптєрєв, Г. Ващенко.

Багато учених-педагогів вважають, що інтегративні процеси стають тенденцією у педагогіці, зокрема в теорії навчання, дедалі більш тісно співдіють дидактика і психологія мислення, педагогічна психологія і соціологія, соціологія і педагогіка загалом, теорія змісту загальної і технічної освіти (А. Беляєва, М. Махмутов, А. Пінський, В. Розумовський, Г. Федорець та ін.).

Сучасна наука, зокрема культура філософії виокремлюють у синергетиці декілька паралельних пластів ї̈ буття, що розташовуються у міру зростання рівня абстрактності: піддисциплінарний - буденна свідомість повсякденних житейських практик; дисциплінарний - процеси індивідуальної творчості й розвиток дисциплінарних знань і об'єктів досліджень; міждисциплінарний - процеси міждисциплінарної комунікації і перенесення знань в діалогах дисциплін; трансдисциплінарний - процеси самоорганізації і функціонування великих міждисциплінарних проєктів; наддисциплінарний - процес творчості, становлення філософського знання, розвиток науки і культури [2, с. 27-28].

Термін інтердисциплінарність (interdisciplinarity) використовується переважно у зарубіжній науковій літературі. Саме слово interdisciplinarity складається з лат. префікса inter., що означає перебування поміж знання та лат. дієслова disciplina - означає вчення, виховання, розпорядок. Відомий методолог Єжи Сух у статті «Роль інтердисциплінарних досліджень в сучасній науці» підкреслює «навіть значимість вченого, його, так би мовити, калібр, можна сьогодні оцінити з огляду широти горизонтів наукових пошуків, тобто діапазону інтердисциплінарних досліджень, якими він займається» $[3$, с. 34].

Вважаємо, що синтез знань, полінауковість, між-, крос- та трансдисциплінарність - це те, чого не вистачає сучасній педагогіці. У педагогічних дослідженнях має реалізуватися міждисциплінарний підхід, оскільки вони грунтуються на вивченні історії, соціології, економіки, демографії та педагогічних закономірностях явищах і процесів. Доцільність реалізації міждисципдінарного підходу у професійній підготовці майбутніх фахівців обгрунтовано у дослідженнях В. Андрущенка, С. Гончаренка, В. Кременя, В. Огнев'юка, С. Сисоєвої та ін., на переконання яких ефективність зміни парадигм освіти, впровадження інновацій у педагогічну підготовку можливо досягти за умови міждисциплінарної основи такої підготовки.

Процитуємо німецького педагога Ф. Фребеля, який підкреслював, що існують епохи, коли освіта стає у центр суспільних інтересів. Це підвищує значимість наук про людину, у першу чергу, значення педагогіки як 
спеціальної науки про освіту, що пройшла багатовіковий шлях розвитку, вирізняється багатоаспектністю науково-теоретичних засад, генезою принципово нових концептуальних напрямів [4].

3 погляду В. Онищенка, «педагогіка як наука й мистецтво концентрує в собі взаємозв'язок і взаємозалежність педагогічно значущих результатів інших гуманітарних наук і філософсько-методологічних підходів до розуміння сутності людини і смислу їі життя - пізнання» [5, с. 7]. Зокрема, ним обгрунтовано, що всі фундаментальні педагогічні теорії (педагогічна антропологія, педагогічна психологія, педагогічна етика, педагогічна естетика, педагогічна герменевтика, педагогічна ноетика, педагогічна когнітологія, педагогічна аксіологія й педагогічна акмеологія) синтезуються в єдиному семантичному полі філософсько-педагогічної ноології.

Вчені зазначають, що інтердисциплінарний підхід у площині наукового аналізу педагогічної реальності розширює межі пізнання сутності досліджуваних явищ, асимілюючи нові дискурси. їх використання у дослідницькому процесі забезпечує розвивальний потенціал теорії і практики навчання, виховання й розвитку особистості. Адже в єдиному фокусі постають різні аспекти методології педагогіки, особливості й умови організації педагогічного впливу, сутнісні характеристики суб'єктів освітнього процесу тощо [6, с. 107].

Так, О. Матвієнко наголошує, що прикметник «міждисциплінарний» часто використовується в освітній сфері, коли дослідники двох або більше дисциплін об'єднують у загальний фонд свої підходи і трансформують їх так, щоб вони стали прийнятними для вирішення певних освітніх проблем. Отже, міждисцплінарність передбачає розгляд предмету з різних сторін i різними методами, пронизуючи дисципліни й утворюючи новий спосіб розуміння предмета [7, с. 88].

Науковці роблять висновок, що українська наука і практика потребують посилення уваги до дослідження наукознавчих педагогічних і психологічних проблем, й особливо - професійної педагогіки, педагогіки і психології праці в умовах навчання упродовж життя, це сприятиме одержанню нового наукового знання, що збагачуватиме методологічний рівень педагогіки [8, с. 299].

\section{Аналіз практичного досвіду реалізації міждисциплінарного підходу}

Інтеграція навчальних предметів має гуртуватися на таких дидактичних положеннях: супідрядність функцій окремих навчальних дисциплін; економічність - ущільнення і концентрація навчального матеріалу, усунення дублювання в його вивченні; сталість інтегративного базису, інтеграція двох навчальних предметів на основі одного з них; наявність достатнього обсягу навчального матеріалу, який може бути вивчений на базі іншої дисципліни $[9$, с. 33].

Ці положення повно розкрито в курсі «Педагогіка». Саме тому в кінці 80-х років I. А. Колеснікова почала готувати нову програму курсу, передбачивши інтеграцію педагогічних курсів «Вступ до вчительської спеціальності», «Дидактика», «Теорія виховання». В основу вивчення курсу покла- 
дено такі провідні ідеї: особистісно-гуманістична орієнтація діяльності педагога; цілісність педагогічного процесу відносно конкретного соціального об'єкта в його життєдіяльності; конструкцій і реконструкцій цілісного процесу через систему методів; доцільності і системності дій педагога. Запропонований варіант програми включає розділи: «Теоретико-методологічні основи педагогіки», «Цілісний навчально-виховний процес», «Організація єдності навчально-виховного процесу» [10].

На початку 90-х рр. організовано апробацію експериментальної програми з педагогіки, що складається з таких розділів: «Теоретико-методологічні основи педагогіки», «Гуманістичні традиції виховання і освіти у вітчизняній і зарубіжній педагогіці», «Практична педагогіка». Виділення розділів відповідає методологічним вимогам просування від абстрактного до конкретного, єдності теорії і практики, розкриття генезису основних педагогічних проблем в їх історичній специфіці і розвитку [11]

На відміну від охарактеризованих вище програм курсу «Педагогіка» в Полтавському педагогічному інституті з 90-х років апробують програму курсу «Теорія та історія педагогіки», в якому інтегровано такі педагогічні дисципліни, як історія педагогіки, дидактики, теорія виховання і школознавство. Програма містить такі розділи: 1. Загальні історикотеоретичні основи педагогіки. 2. Основи національної української педагогіки. 3. Єдність навчання і виховання в цілісному педагогічному процесі (А. Теорія навчання й освіти особистості; Б. Теорія виховання і самовиховання особистості). 4. Проблеми школознавства. В основу вивчення кожного розділу покладено ідеї розбудови української національної школи, особистісно-гуманістичної орієнтації в спілкуванні, діяльності і відносин педагогів і учнів як суб'єктів навчально-виховного процесу [12].

Вітчизняні науковці досліджують також особливості інтердисциплінарного підходу в реалізації проблеми полікультурної освіти майбутніх викладачів закладів вищої педагогічної освіти на практиці і стверджують, що він може реалізуватись шляхом розробки та впровадження спецкурсу, який передбачатиме інтеграцію таких дисциплін, як педагогіка, психологія, філософія, соціологія, історія, етика, право тощо. Зокрема, педагогіка вищої школи дозволяе удосконалити методику підготовки майбутніх викладачів вищих педагогічних навчальних закладів; психологія - розглядає педагога як представника і носія певної культури, тобто піднімає проблему ідентичності у дослідженні загальнокультурного розвитку особистості майбутнього педагога в умовах постіндустріального суспільства; філософія уможливлює теоретичну інтерпретацію феномена культури, як філософської проблеми; соціологія - розкриває проблеми функціонування полікультурного суспільства в епоху глобалізації; історія - досліджує феномен полікультурності як історичне явище; етика - обгрунтовує ціннісні пріоритети сучасного полікультурного суспільства; право - дає можливість проаналізувати нормативні акти міжнародної та національної правових систем стосовно прав і свобод особистості [13, с. 22-23].

Видатний польський учений 3. Вятровський обгрунтував спеціалізацію в педагогіці й запропонував авторську систематизацію педагогічних наук, що охоплює чотири напрями: 
I. Фундаментальні педагогічні дисципліни - педагогіка загальна, історія освіти і виховання та педагогічних доктрин, теорія виховання, дидактика (технології навчання).

II. Основні педагогічні дисципліни, визначені лінією розвитку людини педагогіка сім’ї, педагогіка дошкільна і молодшого шкільного віку, педагогіка шкільна, педагогіка вищої школи, педагогіка дорослих, педагогіка спеціальна, теорія подальшого навчання, теорія неперервного навчання, педагогіка людей третього віку.

III. Педагогічні дисципліни, що відповідають головним напрямам діяльності людини - педагогіка соціальна, педагогіка культури, педагогіка праці, педагогіка здоров'я, теорія загально технологічного виховання, теорія військового виховання, педагогіка вільного часу і рекреації.

IV. Допоміжні та пограничні дисципліни - педагогіка порівняльна, педевтологія, освітня політика, економіка освіти, організація освіти і виховання, філософія виховання, психологія виховання, соціологія виховання, біологія виховання, освітня інформатика і кібернетика $[14$, c.42].

Отже, накопичено значний вітчизняний і зарубіжний досвід впровадження міждисциплінарного підходу у практику підготовки майбутніх педагогів, кожен з них є своєрідним і виконує свої функції.

Метою нашого дослідження є аналіз стану практичної реалізації заявленої проблеми та обгрунтування методологічних принципів щодо впровадження міждициплінарного підходу в організацію педагогічної освіти майбутніх педагогів.

\section{Результати дослідження}

3 метою вивчення стану реалізації досліджуваної проблеми на практиці нами здійснено опитування респондентів щодо використання міждисциплінарного підходу у процесі професійної підготовки майбутніх педагогів.

Опитування проводилося он-лайн (https://www.facebook.com/ipood.napn/ posts/3), впродовж 1 тижня, отже було відкритим, До участі запрошувалися, в першу чергу, викладачі закладів вищої освіти педагогічного профілю, але точка зору викладачів педучилищ і вчителів загальноосвітніх шкіл також була для нас важливою. Анкетування було анонімним, ми просили вказати лише педагогічний стаж, а за бажанням респонденти могли надати і додаткові відомості про себе. Загалом у процесі аналізу ми ураховували думку 100 викладачів закладів вищої освіти із різних регіонів України. Із додатково повідомленої інформації, ми встановили, що в опитуванні брали участь доктори і кандидати педагогічних наук, завідувачі кафедрами, але у найбільшому ступені нас цікавив педагогічний досвід. Як видно із табл. 1, усіх учасників опитування (100 осіб) було розподілено у чотири групи, з яких найбільшою (36 осіб) була група викладачів з педагогічним стажем від 11 до 20 років. 
Таблиця 1. Розподіл учасників опитування за педагогічним стажем

\begin{tabular}{|c|c|c|c|c|}
\hline \multicolumn{4}{|c|}{ Вікові групи } & \multirow{2}{*}{$\begin{array}{l}\text { Кількість } \\
\text { осіб }\end{array}$} \\
\hline Від 4 до 10 & Від 11 до 20 & Від 21 до 30 & Понад 30 & \\
\hline 24 & 36 & 32 & 8 & 100 \\
\hline
\end{tabular}

Опитування передбачало з'ясування ряду питань щодо розуміння викладачами закладів вищої освіти, зокрема: сутності поняття «Міждисциплінарний підхід»; особливостей застосування міждисциплінарного підходу в професійній підготовці педагогів; способів взаємодії з колегами у реалізації міждисциплінарного підходу; впливу міждисциплінарного підходу на планування навчального процесі у закладі освіти; виявлення позитивних і негативних тенденцій, а також труднощів які виникають у процесі використання міждисциплінарного підходу.

Прокоментуємо відповіді на окремі питання.

Запитуючи наших респондентів з яким іншим словом більшою мірою у них асоціюється інтердисципінарність, ми виходили з того, що асоціації виникають не лише на основі схожості явищ та подій, але й на основі їх протиставлення, оскільки протиставлятися може лише те, що має спільне коріння. Сам термін асоціація (лат. associo - «з'єдную», «зв'язую») означає поняття, що виникає при згадуванні іншого i, на думку Дж. Локка, $є$ важливим засобом розвитку творчого мислення, основним механізмом утворення складних ідей. Суб'єктивно-ідеалістичний напрям асоціативної психології трактує асоціації як специфічні утворення внутрішнього світу людини, відображені у її свідомості і загалом за створеними асоціаціями можна сформувати судження про суб'єктивне сприйняття людиною навколишньої дійсності.

Серед чотирьох варіантів відповідей: взаємодія (сумісна дія кількох об'єктів або суб'єктів); взаємодоповнення (додавати щось один одному); поєднання (об'єднувати, сполучати) і зв'язок (широкий термін, використовуваний у комунікації, техніці, механіці, хімії, системному аналізі, має широке тлумачення: від передаванні сигналів на відстань, чи співвідношення між різними компонентами факторами, явищами, подіями до взаємозалежності і взаємообумовленості) перше місце посіла відповідь «взаємодія», друге - взаємодоповнення (Рис. 1).

У $46 \%$ респондентів специфічними утвореннями по відношенню до міждисциплінарного підходу є сумісна дія, додавання, допомога іншому. Слід додати, що більшість викладачів третьої і четвертої групи обрали саме цю відповідь. Викладачі з невеликим педагогічним досвідом обирала відповідь «поєднання», натомість найбільш досвідчені - надавали перевагу варіанту «зв'язок».

На нашу думку, питанням щодо доцільності підготовки майбутнього вчителя до інтердисциплінарної взаємодії мало передувати з'ясування думки чи потрібна взагалі така взаємодія та рівень їі використання на практиці. У своїх відповідях тільки третина опитаних повідомила, що така взаємодія потрібна і вони завжди їі використовують. Тоді як $62 \%$ ре-

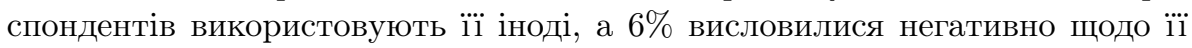
використання (Рис. 2). 


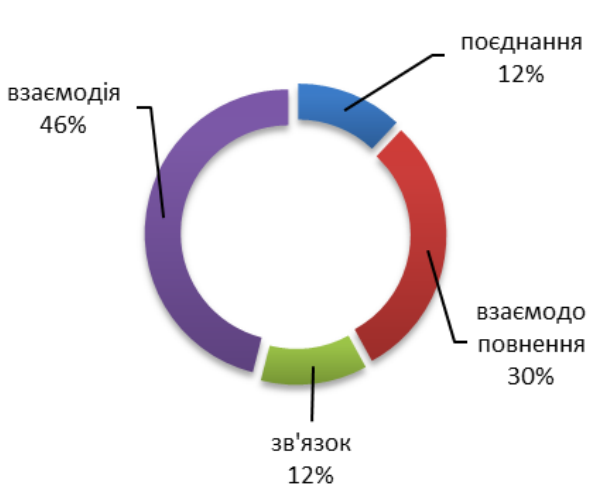

Рис. 1. 3 яким словом у Вас найбільшою мірою асоціюється у поняття «Міждисциплінарний підхід»

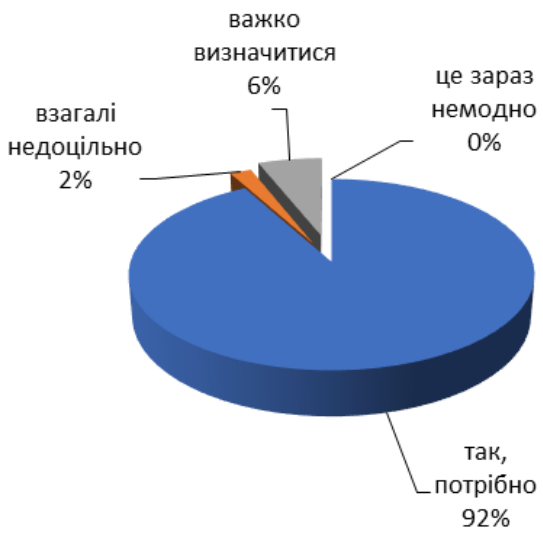

Рис. 3. Чи вважаєте Ви за потрібне готувати майбутніх педагогів до реалізації міждисциплінарного підходу у професійній діяльності

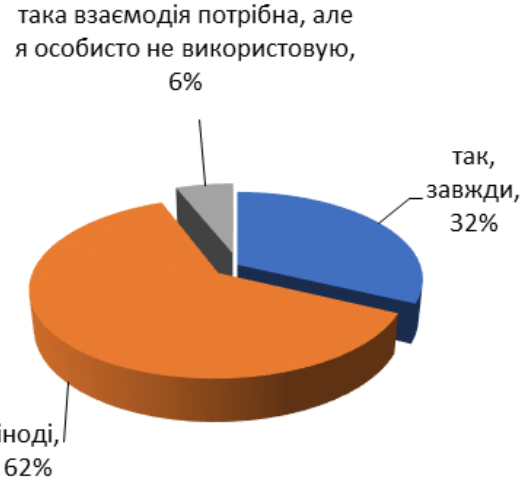

Рис. 2. Чи взаємодієте Ви з колегами у реалізації міждисциплінарного підходу? Чи потрібна взагалі Вам така взаємодія?

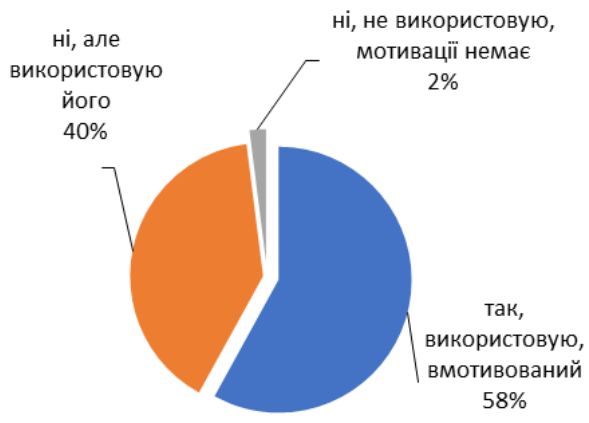

Рис. 4. Чи вмотивовані Ви до викори-стання міждисциплінарного підходу у підготовці майбутнього педагога?

Вище ми наголошували, що, з одного боку, інтегративні процеси відтворюють міжпредметний підхід у педагогічній підготовці майбутніх учителів, уможливлюють її ефективність, а з іншого, стають передумовою для підтвердження доцільності підготовки майбутніх педагогів до реалізації міждисциплінарного підходу у професійній діяльності. Отже, відповідаючи на наше запитання щодо доцільності такої підготовки, абсолютна більшість респондентів (92\%) дали позитивну відповідь. Відповідь - не модно, не доцільно, важко визначитися - обрали загалом $8 \%$ опитаних (Рис. 3).

На нашу думку, у реалізації на практиці будь-якої ідеї велику роль відіграє мотиваційний чинник. Результати вивчення мотивації можуть стати вихідною позицією для створення засобів її формування, розвитку або корекції вже існуючої мотиваційної сфери. Цей аспект є надзвичайно важливим не тільки для викладачів закладів вищої освіти, але й до потенційних педагогів, мотивація яких ще остаточно не сформована, або через сукупність причин знаходиться на низькому рівні. Отже наступне запитання стосувалося рівня вмотивованості до використання міждисциплінарного 
підходу у підготовці майбутнього педагога. Загалом дуже високий відсоток опитаних (98\%) запевнили, що використовують міждисциплінарний підхід на практиці, проте $58 \%$ з них підкреслили, що вмотивовані до такої дії, натомість $40 \%$ - використовують, хоча мотивація до цього у них відсутня (Рис.4). Намагаючись прослідкувати динамічну залежність між вмотивованістю до використання міждисциплінарного підходу у підготовці майбутнього педагога і наявним педагогічним досвідом, ми зіставили відповідні показники. Така закономірність, на нашу думку, є надзвичайно важливою. Отже конкретизація отриманих результатів показала, що викладачів 1-ї та 2-ї груп невмотивовані, але використовують цей підхід на практиці. Тоді як представники 3-ї групи із педагогічним стажем понад 20 років мають таку мотивацію і реалізують їі.

Результати здійсненого опитування респондентів покладено в основу обгрунтованих нами принципів міждисциплінарного підходу до побудови змісту професійної психолого-педагогічної підготовки майбутніх педагогів.

\section{Узагальнення теоретичного і практичного стану проблеми}

Для продуктивного засвоєння знань з різних дисциплін важливим є встановлення широких зв'язків між ними, тому що жодна навчальна дисципліна сама по собі у відриві від інших дисциплін неспроможна сформувати професійну компетентність майбутнього педагога.

Як стверджують науковці, педагогічний процес - це синтетична модель викладання і навчання, яка потрібна для теоретичного усвідомлення змісту, структури і функцій педагогічної освіти. Головним принципом побудови і реалізації цієї моделі є цілісність. Ефективність такої підготовки залежить від рівня усвідомлення викладачами і студентами педагогічного процесу як цілісного, як інтегративного результату керування власною діяльністю [15, с. 65$]$

Цілісний зміст професійної підготовки майбутнього педагога має забезпечити: формування якостей і властивостей особистості, які визначають психологічну готовність до педагогічної роботи, ㄲï спрямованість, а також теоретичних знань про закономірності педагогічного процесу, форми і способи його організації; розвиток практичних умінь і навичок організації навчального процесу, керівництво ним в конкретних педагогічних умовах.

Зміст навчання у закладах педагогічної освіти потрібно формувати в таких двох напрямах: по-перше, забезпечувати становлення особистості студента в сукупності його індивідуальних якостей і особливостей. У цьому випадку навчально-виховний процес будують за логікою індивідуального розвитку студента; по-друге, в конкретній сфері соціального досвіду, яка надалі буде засобом і змістом його професійно-педагогічної взаємодії з учнями. Конкретна сфера соціального досвіду дає змогу спеціалісту забезпечувати професійно-педагогічну взаємодію з майбутніми вихованцями.

Отже, педагогічна освіта, на відміну від інших типів професійної підготовки, повинна давати системні знання про людину як суб'єкта освітнього процесу, що включає навчання і виховання. Ця системність задається не стільки включенням відповідних дисциплін у навчальний план, скільки 
всім контекстом навчання у педагогічному навчальному закладі, коли кожну дисципліну розглядають, з одного боку, як засіб загального розвитку майбутніх педагогів, а з іншого, - як основу їхньої майбутньої діяльності, спрямованої на розвиток школярів.

\section{Принципи впровадження міждисциплінарного підходу}

Узагальнено інтердисциплінарність можна тлумачити як поєднання різних галузей знань. Характерною особливістю інтердисциплінарного (міждисциплінарного) підходу є наявність «основної» і «додаткової» дисципліни. Ми опираємося на інтердисциплінарний підхід, оскільки педагогіка у нашому дослідженні $є$ «основною» дисципліною, а усі інші дисципліни, про які буде йтиметься далі - $е$ «додатковими».

Зміст дисциплін психолого-педагогічного циклу необхідно спрямовувати на усвідомлення способів пізнання педагогічної діяльності і формування психолого-педагогічних умінь, які забезпечують успішність педагогічної дії, зокрема: засвоєння психолого-педагогічних знань як системи; співвідношення систем знань між собою, перегляд їх відповідно до завдань пізнання і конкретних умов використання; засвоєння не тільки знань, але й способів їх застосування на практиці, а також добування нових. При цьому засобами їх реалізації слугують внутрішньопредметні і міжпредметні зв'язки, які визначають логіку навчальної інформації, її структуру; системні категорії, за допомогою яких системні об'єкти наповнюються конкретним педагогічним змістом.

Відповідно нами обгрунтовано принципи міждисциплінарного підходу до побудови змісту професійної психолого-педагогічної підготовки майбутніх педагогів.

Основним є принцип цілісності. Він зумовлений діалектичним розумінням навколишньої дійсності і дає уявлення про наявність зв'язків між елементами і явищами в природі і суспільному житті.

Сутність цілісності в освітньому процесі полягає в підпорядкуванні всіх його компонентів, частин і функцій головному - формуванню цілісної особистості майбутнього педагога. Цілісність можна розглядати на різних рівнях, зокрема: усього навчального-виховного процесу; циклу предметів; окремо взятого предмета; одиниць знань, що засвоюються. Цілісність педагогічного процесу потрібно враховувати вже на стадії розробки навчальних програм і реально забезпечувати тільки за умови додержання основних аспектів: повноти і єдності освітньої, виховної і розвивальної мети навчання; повноти взаємозв'язку і концептуальності змісту; комплексного використання методів, прийомів і засобів навчання $[16$, с. 9].

Згідно з принципом системності потрібно комплексно підходити й до визначення змісту підготовки педагогів у закладі вищої освіти. Щоб реалізувати його треба розробити такий зміст освіти майбутнього педагога, що Ірунтується на комплексній цільовій програмі і зорієнтований на кінцеві результати, а не є звичайною сумою незалежних одна від одної автономних дисциплін. Зміст кожної дисципліни слід розглядати як органічну частину цілісного змісту всебічної підготовки спеціаліста певного профілю [17, c. 31]. 
Цикл психолого-педагогічних дисциплін у закладі вищої педагогічної освіти інтегрує сукупність усіх тих явищ, які можна умовно назвати людинознавчими. Загальна професійна психолого-педагогічна підготовка виконує важливі соціальні і професійні функції: забезпечує розвиток загальної і професійної культури майбутніх учителів, педагогічного мислення, професійно важливих якостей. Це системоутворювальна професійна підготовка педагога будь-якого рівня.

Психолого-педагогічна підготовка включає вивчення в процесі навчання таких дисциплін: педагогіки, загальної психології, вікової і педагогічної психології, основ педагогічної майстерності, основ наукових досліджень. Комплексною цільовою програмою вивчення цих дисциплін передбачено, по-перше, їх узгодження в часі, по-друге, додержання наступності і логіки вивчення, використання міжпредметних зв'язків. Основні курси опановують протягом п'яти семестрів, а загалом професійно-педагогічна підготовка триває весь період навчання в закладі освіти, включає й альтернативні спецкурси, узагальнення психолого-педагогічних умінь у процесі педагогічної практики, написання рефератів, курсових і дипломних робіт.

Провідним у системі загальнопедагогічної підготовки майбутніх педагогів є курс «Педагогіки», оскільки він концентрує в собі методологічні, теоретичні і методичні основи освітнього процесу. Усе це було підставою для розроблення авторської програми цілісного курсу «Теорія та історія педагогіки». Важливу роль у професійному становленні вчителя відіграє курс «Психологія», оскільки вивчає умови і основні закономірності формування особистості, розвитку її психічних процесів та індивідуальнопсихологічних особливостей сприяє самопізнанню студентів й організації їхнього саморозвитку; дає уявлення про психологію педагогічної діяльності, сприяє формуванню педагогічних здібностей і умінь. Єдність курсів педагогіки і психології забезпечує загальнотеоретичний фундамент професійної підготовки вчителя. У свою чергу, вони тісно пов'язані з курсом «Основи педагогічної майстерності», в якому розкрито сутність майстерності сучасного вчителя і визначено шляхи її становлення, зокрема система формування культури мислення, спілкування, навичок саморегуляції поведінки, елементи тренінгу психофізичного апарату вчителя і педагогічний тренінг для моделювання ситуацій під час розв'язання професійних завдань. Цей курс є педагогіко-технологічним фундаментом професійної підготовки вчителя.

До психолого-педагогічної підготовки включено курс «Основи наукових досліджень», що визначає шляхи наукової творчості особистості майбутнього педагога в системі її професійного становлення. Науково-педагогічні дослідження, як відомо, є джерелом наукової педагогіки і психології. Вони сприяють їх розвитку, забезпечують формування індивідуальності майбутнього педагога [18, с. 132-140].

Отже, можна виділити такі напрями взаємозв'язку психолого-педагогічних дисциплін: забезпечення наступності в розвитку знань, у формуванні понять, спільних для психолого-педагогічних дисциплін; здійснення єдиного підходу до формування педагогічних умінь і навичок, систематизації і узагальнення знань, набутих у процесі вивчення циклу дисциплін; уникнення дублювання у вивченні одних і тих самих питань під час викла- 
дання різних дисциплін; формування педагогічного мислення, вироблення вміння розглядати педагогічні явища діалектично, у взаємозв'язку, визначати причини явищ та їх наслідки; аналіз педагогічних фактів і явищ 3 точки зору фізіології, психології, педагогіки.

Принцип структурності, згідно з яким предмети і явища розглядають як певним чином організовані системи, що мають внутрішню будову або структуру. У структурі власне професійно-педагогічної підготовки можна виділити три основні блоки: загальнотеоретичні знання; педагогікотехнологічні знання; базові професійно-педагогічні вміння.

Фундаментальні теоретичні знання умовно поділяємо на три структурні концепти. Перший - охоплює загальнофілософські проблеми виховання, що візуалізують його як: 1) засіб розвитку особистості, організації взаємодії загальнолюдської, конкретно-історичної і національної культури, умову засвоєння загальнолюдських і вироблення індивідуально-особистісних цінностей; 2) соціальне і біологічне в структурі людської особистості (суб'єкт - суб'єктні відносини в процесі навчально-виховної діяльності; врахування вікових, статевих та індивідуальних особливостей у педагогічному процесі); 3) закономірні зв'язки між моральним, розумовим, естетичним, екологічним і фізичним вихованням; 4) функції громадських організацій у вихованні підростаючих поколінь (вплив на формування особистості мікросоціуму; особистість вчителя в теорії і практиці педагогіки). Зміст другого концепту стосується теорії освіти і навчання. Узагальнено його структуру можна окреслити такими проблемами: сучасні концепції змісту освіти в їх історичному розвитку; демократизація і гуманізація педагогічного процесу; виховальне і розвивальне навчання; організаційні форми і методи навчання; мотивація навчально-пізнавальної діяльності особистості і формування позитивного ставлення до неї; диференціація й індивідуалізація навчання тощо. Третій концепт включає питання, що стосуються організаційних аспектів народної освіти: концепція безперервної багаторівневої освіти та її генезис; системи народної освіти за кордоном, їх побудова і принципи організації діяльності в сучасних умовах; навчально-виховні заклади, проблеми і перспективи їх розвитку.

Педагогіко-технологічні знання забезпечують педагогічну підготовку майбутніх педагогів із технологічних позицій, зокрема: навчальні програми, підручники і методики їх використання залежно від профілю діяльності майбутнього педагога; системи засобів навчання і методики їх використання; способи спілкування педагога; організація педагогічної дії з використанням різних форм і видів пізнавальної діяльності; перевірка й оцінка знань, умінь і навичок тощо. Останній блок - формування базових професійно-педагогічних умінь, зокрема: діагностичних, прогностичних, організаційних, комунікативних, демократичного спілкування, аналітичних.

Наведену структуру психолого-педагогічної освіти конкретизовано в розробленій і науково обгрунтованій системі спеціальної науково-методичної підготовки вчителя.

Принцип інтегративності, філософська сутність якого полягає у тому, що кожний компонент певної системи існує лише у взаємозв'язку з іншими компонентами. Порівняно з діючими програмами у запропонований 
нами варіант міжпредметної взаємодії внесені суттєві змістовні, логічні, структурні зміни, передбачено інтеграцію навчального матеріалу педагогіки, історії педагогіки, порівняльної педагогіки, етнопедагогіки, соціальної педагогіки і філософії.

Принцип ієрархічності, який свідчить, що кожна система, котру вивчають, в одному випадку є підсистемою системи вищого порядку, а в іншому - кожний компонент системи, яку аналізують є підсистема даної системи. Так, зміст професійно-педагогічної освіти є підсистемою психологопедагогічної підготовки майбутнього педагога. Зміст кожної дисципліни психолого-педагогічного циклу - підсистема системи його цілісного змісту. Кожна з цих дисциплін підпорядкована одна одній і характеризується певною логікою викладання теоретичних і технологічних знань, а також формування практичних умінь і навичок.

Іерархічність вивчення психолого-педагогічних дисциплін забезпечує така логіка: формування теоретичних знань про особливості організації цілісного педагогічного процесу і особистості студента в ньому; формування педагогічних умінь для роботи з особистістю.

\section{Висновки}

Сучасність висуває до педагогічної науки складні завдання, що потребують поєднання (інтеграції, взаємодоповнення, зв'язку) різних дисциплін, з метою цілісного погляду на здійснюване дослідження. Застосування інтердисциплінарного підходу є одним із шляхів вирішення даної проблеми, а також передумовою формування нового типу дослідницької діяльності і організації (виробництва) наукового знання, який у філософії науки отримав назву «постнекласична наука». Як методологічний орієнтир сучасної педагогічної науки, формування суб'єка педагогічної дії потребує створення системи знань про його зміст з опертям на філософсько-психологічне осмислення суб'єктної сутності особистості та означених особливостей розгляду особистості в умовах освітньо-виховного процесу. Насамперед - це людиновимірний контекст розкриття змістових, рівневих і функціональних проявів особистості в інтердисциплінарному дискурсі, до якого має долучитися й педагогічна наука.

Таким чином, проаналізувавши теоретичний і практичний стан реалізації міждисциплінарного підходу у підготовці майбутніх педагогів, ми визначили методологічні принципи які мають бути в основі організації освітнього процесу підготовки майбутніх педагогів: цілісність, системність, структурність, інтегративність, ієрархічність.

\section{Література}

[1] Вознюк, О. В., Дубасенюк, О. А. 2009. Цільові орієнтири розвитку особистості у системі освіти: інтегративний підхід: монографія. Житомир: Вид-во ЖКДУ ім. І. Франка.

[2] Кремень, В. Г., Ільїн, В. В. 2012. Синергетика в освіті: контекст людиноцентризму: монографія. Київ: Пед. Думка. 
[3] Such, J. 1998. Rola badań interdyscyplinarnych we współczesnej nauce. Humaniora\|. Biuletyn. Poznań, nr 8.

[4] Фребель, Ф. 2001. Будемо жити для своїх дітей. Педагогіка дитинства / Упоряд. і перед. Л. М. Волобуєва. Москва.

[5] Онищенко, В. Д. 2014. Фундаментальні педагогічні теорії. Львів: Норма.

[6] Галян, О. 2018. Специфіка інтердисциплінарної співдії в інтерпретації суб'єктності особистості як педагогічної реальності. Людинознавчі cmyдï : зб. наук. праць ДДПУ імені Івана Франка. Серія «Педагогіка», 6:38.

[7] Матвієнко, О. 2013. Від міждисциплінарності до трансдисциплінарності: наукові підходи вчених світу. Interdyscyplinarnosc pedagogiki $i$ jej subdyscypliny / Pod red. Z. Szaroty, F. Szioska. Wydawnictwo Naukowe Instytutu Technologi Ekxploatacji.

[8] Ничкало, Н. 2013. Система «Людина-Праця» як основа інтердисциплінарності педагогічної науки. Interdyscyplinarnosc pedagogiki i jej subdyscypliny / Pod red. Z. Szaroty, F. Szioska. Wydawnictwo Naukowe Instytutu Technologi Ekxploatacji.

[9] Сидоренко, В. К. 1992. Проблема актуальна, різнобічна. Про інтеграцію навчальних предметів у педагогічній теорії і практиці. Рідна школа, 7-8.

[10] Педагогика: программы для педагогических институтов. 1989 / Сост. И. А. Колесникова. Ленинград: ЛГПИ,

[11] Прасолова, Е.Л. 1993. Курс педагогики: каким ему быть? Педагоги$\kappa a, 1$.

[12] Бойко, А. М., Пащенко В. О. 1994. Науково-методичне забезпечення професійно-педагогічної підготовки вчителя в умовах різнорівневої освіти. Вища педагогічна освіта: наук. метод. зб. Вип. 17.

[13] Теоретичні і методичні засади полікультурної освіти викладача вищого навчального закладу: методичні рекомендації. 2013 / Укладач Л. Ю. Султанова. Київ: ІПООД.

[14] Współczesne problemy nauk pedagogicznych w wybranych krajach Europy. 2007. Środkowowschodniej / Pod redakcją Ewy Filipiak, Ryszarda Gerlacha, Krzystofa Jakubiaka. Bydgoszcz.

[15] Глузман, А.В. 1997. Университетское педагогическое образование: Опыт системного исследования. Киев: Просвіта.

[16] Загвязинский, В. И. 1986. О противоречиях становления целостности учебного процесса. Теоретико-методологические проблемы учебно-воспитательного прочесса в школе и педвузе. Волгоград.

[17] Каган, В.И., Сычеников И.А. 1987. Основы оптимизации процесса обучения в высшей школе Единая методологическая система инстиmута: теория и практика: науч.-метод. пособие. Москва: Высшая шк.

[18] Хомич, Л. О. 1998. Професійно-педагогічна підготовка вчителя початкових класів: монографія. Київ: «Магістр-S». 


\section{References}

[1] Vozniuk, O. V., Dubaseniuk, O. A. 2009. Tsilovi oriientyry rozvytku osobystosti u systemi osvity: intehratyvnyi pidkhid: Monohrafiia. Zhytomyr: Vyd-vo ZhDU im. I. Franka.

[2] Kremen, V.H., Il'in, V. V. 2012. Synerhetyka v osviti: kontekst liudynotsentryzmu: monohrafiia. Kyiv: Ped. Dumka.

[3] Such, J. 1998. Rola badań interdyscyplinarnych we współczesnej nauce. Humaniora\|. Biuletyn. Poznań, nr 8.

[4] Frebel, F. 2001. Budemo zhyty dlia svoikh ditei. Pedahohika dytynstva / Uporiad. i pered. L. M. Volobuieva. Moskva.

[5] Onyshchenko, V. D. 2014. Fundamentalni pedahohichni teorii. Lviv: Norma.

[6] Halian, O. 2018. Spetsyfika interdystsyplinarnoi spivdii v interpretatsii sub'iektnosti osobystosti yak pedahohichnoi realnosti. Liudynoznavchi studii: zb. nauk. prats DDPU imeni Ivana Franka. Seriia «Pedahohika», 6, 38.

[7] Matviienko, O. 2013. Vid mizhdystsyplinarnosti do transdystsyplinarnosti: naukovi pidkhody vchenykh svitu. Interdyscyplinarnosc pedagogiki $i$ jej subdyscypliny / Pod red. Z. Szaroty, F. Szioska. Wydawnictwo Naukowe Instytutu Technologi Ekxploatacji.

[8] Nychkalo, N. 2013. Systema «Liudyna-Pratsia» yak osnova interdystsyplinarnosti pedahohichnoi nauky. Interdyscyplinarnosc pedagogiki i jej subdyscypliny / Pod red. Z. Szaroty, F. Szioska. Wydawnictwo Naukowe Instytutu Technologi Ekxploatacji.

[9] Sydorenko, V. K. 1992. Problema aktualna, riznobichna. Pro intehratsiiu navchalnykh predmetiv u pedahohichnii teorii i praktytsi. Ridna shkola, $7-8$.

[10] Pedahohyka. Prohrammы dlia pedahohycheskykh ynstytutov. 1989. / Sost. Y. A. Kolesnykova. Leningrad: LHPY,

[11] Prasolova, E. L. 1993. Kurs pedahohyky: kakym emu byt? Pedahohyka, 1.

[12] Boiko, A. M., Pashchenko V. O. 1994. Naukovo-metodychne zabezpechennia profesiino-pedahohichnoi pidhotovky vchytelia $\mathrm{v}$ umovakh riznorivnevoi osvity. Vyshcha pedahohichna osvita. Nauk. metod. zb., vyp. 17.

[13] Teoretychni i metodychni zasady polikulturnoi osvity vykladacha vyshchoho navchalnoho zakladu: metodychni rekomendatsii. 2013 / Ukladach L. Iu. Sultanova. Kyiv: IPOOD.

[14] Współczesne problemy nauk pedagogicznych w wybranych krajach Europy 2007. Srodkowowschodniej. Pod redakcją Ewy Filipiak, Ryszarda Gerlacha, Krzystofa Jakubiaka. Bydgoszcz,

[15] Hluzman, A. V. 1997. Unyversytetskoe pedahohycheskoe obrazovanye: Opyt systemnoho yssledovanyia. Kyiv: Prosvita.

[16] Zahviazynskyi, V. Y. 1986. O protyvorechyiakh stanovlenyia tselostnosty uchebnoho protsessa. Teoretyko-metodolohycheskye problemы uchebnovospytatelnoho protsessa v shkole y pedvuze. Volhohrad.

[17] Kahan, V.Y., Suchenykov Y.A. 1987. Osnovы optymyzatsyy protsessa obuchenyia v vыsshei shkole (Edynaia metodolohycheskaia systema ynstytuta: teoryia y praktyka): Nauch.-metod. posobye. Moskva: Vыsshaia shk.

[18] Khomych, L. O. 1998. Profesiino-pedahohichna pidhotovka vchytelia pochatkovykh klasiv: monohrafiia. Kyiv: "Mahistr-S". 